\title{
EUROPEAN EXPERIENCE OF SMART GRIDS IMPLEMENTATION UNDER CONDITIONS OF ENERGY MARKET REFORMS
}

\section{ЄВРОПЕЙСЬКИЙ ДОСВІД РОЗБУДОВИ РОЗУМНИХ МЕРЕЖ В УМОВАХ РЕФОРМУВАННЯ ЕНЕРГЕТИЧНОГО РИНКУ 1}

\author{
Iryna S. Marekha \\ I. C. Mapexa, \\ ukr_irina@ukr.net \\ ORCID: 0000-0002-9905-7706 \\ канд. екон. наук, ст. викладач \\ Sumy State University, Sumy \\ Сумський державний університет, м. Суми
}

\begin{abstract}
The aim of the article is to estimate the foreign experience of smart grids implementation which serve as efficient drivers for power transformations. Methodical foundation of the research is the processing and analysis of the relevant statistical information taken from the international and local resources. During the undertaken research, it was found out that the necessity for reforming the European Union's energy market is determined by the following factors: leveling of the problem of growing needs in energy resources, overcoming the problem of relying on imported energy resources, the importance of integration processes and formation of the single energy market, energy saving and liquidation of energywastefulness in industry and housing. The author states that the intellectually-based model of the European energy market is actually represented by three key components: Smart Grids, Smart Meters, and Smart Cities. But from conceptual point of view, the European market of the electric an energy resources performs on the base of Smart Grids model. The current and prognostic estimates of the market segment for smart energy technologies are given in the research. It is proposed to consider the state of energy sector reforms align with the analysis of the European programs on energy efficiency. It is stressed that performance of the reforms in the energy sector of the EU is determined by prudent, legally adopted documents being mentioned in the article. The author has analyzed the European smart metering projects. The environment al and economic effects caused by the implementation of smart technologies are mentioned in addition. The new conceptual contribution is an author's intellectually-based model grounded for the European Union's energy market. In authors' opinion, such model must include "smart" markets and "smart" consumers. The applicability of the research outcomes implies the formation of new European energy standards which are the priority for each developed country.
\end{abstract}

Key words: energy market; energy reforms; smart grids; smart metering; smart cities; European Union.

Анотація. Мета статті - оцінити закордонний досвід імплементації розумних мереж як ефективних драйверів енергетичних перетворень. Методичним підгрунтям дослідження є опрацювання й аналіз релевантної статистичної інформації, отриманої з міжнародних та національних джерел. У процесі проведеного дослідження було встановлено, що необхідність реформування енергетичного ринку Свропейського Союзу зумовлена такими чинниками, як: нівелювання проблеми зростаючої потреби в енергоресурсах, подолання проблеми імпортозалежності, важливість інтеграційних процесів та формування єдиного енергетичного ринку, енергозбереження та ліквідація енерговитратності у промисловості та житловому комплексі. Автором встановлено, що інтелектоцентрична модель європейського енергетичного ринку фактично представлена трьома ключовими складовими частинами: розумними мережами (Smart Grids), розумними вимірювальними системами та приладами обліку (Smart Metering) та розумними будинками (Smart Cities). Проте концептуально функціонування європейського ринку електроенергетичних ресурсів відбувається на базі основної моделі Smart Grids. У дослідженні наводяться поточні та прогностичні оцінки ринкового сегмента розумних енергетичних технологій. Запропоновано розглядати стан реформ енергетичного сектора у площині аналізу європейських програм з енергоефективності. Підкреслено, що результативність реформ в енергетичному секторі Свросоюзу зумовлена продуманими, законодавчо закріпленими документами, які згадуються у статті. Автором проаналізовано європейські проєкти з інтелектуального обліку енергоспоживання. Додатково наведені екологічні й економічні ефекти від імплементації розумних технологій. Новим концептуальним внеском є обгрунтована автором інтелектоцентрична модель енергетичного ринку Європейського Союзу. На думку автора, така модель повинна включати «розумні» ринки та «розумних» споживачів. Практична значущість результатів дослідження полягає у формуванні нових європейських енергетичних стандартів, наближення до яких є пріоритетом кожної розвинутої країни.

Ключові слова: енергетичний ринок; енергетичні реформи; розумні мережі; розумні лічильники; розумні міста; Європейський Союз.

\footnotetext{
${ }^{1}$ Роботу виконано в межах науково-дослідної теми № 0119U100766 «Оптимізаційна модель розбудови розумних та безпечних енергетичних мереж: інноваційні технології екологізації підприємств та регіонів».
} 


\section{ПОСТАНОВКА ЗАДАЧІ}

Реформування енергетичного ринку в напрямі підвищення ефективності його функціонування шляхом запровадження розумних технологій є основою європоцентричної моделі енергетичної безпеки. Така модель передбачає утворення єдиного енергетичного союзу через інтелектуалізацію енергопостачання та споживання. Саме завдяки просуванню ідеї широкомасштабного використання розумних енергетичних мереж від побутового рівня до промислового користування стає можливим створення конкурентоспроможного та безпечного енергетичного сектора у країнах Європейського Союзу. Структурно європейський енергетичний сектор представлений ринками нафти i газу, вугілля, електроенергії та відновлювальних джерел енергії, частка яких постійно зростає. Проте вирішальне значення на європейському енергетичному ринку відводиться саме енергозбереженню й усуненню енерговитратності виробництва. Ключову роль у досягненні задекларованої мети відіграють розумні енергетичні мережі, імплементація яких є об'єктом реформування енергетичного ринку в сучасних умовах. Саме домінування таких ринкових тенденцій визначає рівень європейських енергетичних стандартів, наближення до яких є пріоритетом української енергетики. Розбудова української енергетичної системи на базі європейського досвіду впровадження розумних мереж становить актуальне завдання.

\section{АНАЛІЗ ОСТАННІХ ДОСЛІДЖЕНЬ І ПУБЛІКАЦІЙ}

Питання оцінки національної енергетичної ефективності та шляхи іiі підвищення вивітлювалися в роботах А. Іскакова, І. Кобушка [1], Л. Кицкай [2], О. Суходолі [3], О. Бархатова [4] та ін. Дослідженням закордонного досвіду гарантування енергетичної безпеки на основі впровадження концепції розумних технологій присвячені праці Ю. Матвєєвої, С. Колосок, І. Вакуленка [5], В. Матюшок, С. Бруно, С. Балашової, К. Гомонова [6] та ін. Відзначаючи вагомий внесок згадуваних авторів у формування теоретикометодологічних підходів до аналізу проблеми енергоефективності, варто вказати на невирішені частини досліджуваної проблеми.

\section{ВІДОКРЕМЛЕННЯ НЕВИРІШЕНИХ РАНІШЕ ЧАСТИН ЗАГАЛЬНОЇ ПРОБЛЕМИ}

Завдяки задекларованому Україною курсу на європейську інтеграцію актуалізуються питання, пов'язані $з$ дотриманням європейських норм і стандартів. У зв'язку із цим Україна повинна приєднатися до спільної з європейськими країнами енергетичної політики, що стає неможливим без вивчення кращого європейського досвіду реформування енергетичного ринку. У сучасних умовах Свропейський Союз є активним імплементатором інтелектуальних енергосис- тем, які засвідчують свою ефективність у промисловості та популярні серед населення.

Мета дослідження - зробити аналіз європейського досвіду імплементації розумних енергетичних мереж і обгрунтувати нову, інтелектоцентричну модель енергетичного ринку для країн Свропейського Союзу (далі- $\mathrm{CC}$ ).

\section{МЕТОДИ, ОБ'ЄКТ ТА ПРЕДМЕТ ДОСЛІДЖЕННЯ}

Методичним підгрунтям дослідження є опрацювання й аналіз релевантної статистичної інформації, отриманої з міжнародних та національних джерел. Об'єктом дослідження є економічні відносини, що виникають між учасниками енергетичного ринку у країнах ЄС. Предмет дослідження - процеси впровадження розумних мереж у контексті реформування енергетичного ринку.

\section{ОСНОВНИЙ МАТЕРІАЛ}

Світова енергетика перебуває у процесі кардинальних змін. У сучасних умовах відбувається інтенсивне впровадження інноваційних технологій, серед яких провідне місце посідають розумні мережі Smart Grids. Європейська комісія трактує Smart Grid як «електричні мережі, які можуть економічно ефективно інтегрувати процеси генерації та споживання електроенергії, забезпечуючи мінімізацію втрат під час передавання та розподілу електричної енергії, високий рівень якості, надійності і безпеки» [7, с. 45].

Економічна оцінка сегмента розумних мереж у глобальному плані представлена на рис. 1. За прогнозними оцінками, європейський ринок розумних мереж у 2023 р. наблизиться до рівня 15,4 млрд дол.

Європейська енергетика має суттєвий потенціал для залучення інвестицій. За індексом інвестиційної привабливості відновлювальної енергетики (RECAI) у 2019 р. країни Європейського Союзу так розподілилися за рейтинговими позиціями (Таблиця 1).

Таблиця 1. Індекс інвестиційної привабливості відновлювальної енергетики у країнах Європейського Союзу, 2019 р. [9]

\begin{tabular}{|c|c|c|c|}
\hline Країна & $\begin{array}{c}\text { Місце } \\
\text { в рейтингу }\end{array}$ & Країна & $\begin{array}{c}\text { Місце } \\
\text { в рейтингу }\end{array}$ \\
\hline Франція & 3 & Ірландія & 23 \\
\hline Німеччина & 6 & Португалія & 25 \\
\hline Нідерланди & 10 & Греція & 30 \\
\hline Данія & 12 & Швеція & 32 \\
\hline Італія & 18 & Фінляндія & 39 \\
\hline Бельгія & 21 & \multicolumn{3}{|l}{} \\
\hline
\end{tabular}

Однак, незважаючи на вагомі здобутки, перед Євросоюзом постають і серйозні виклики. Згідно 3 оцінками Міжнародного енергетичного агентства, Свропейський Союз як індустріально розвинутий регіон у майбутньому буде відчувати суттєву потребу в 
ЕКОНОМІКА ТА МЕНЕДЖМЕНТ № 4ロ 2019

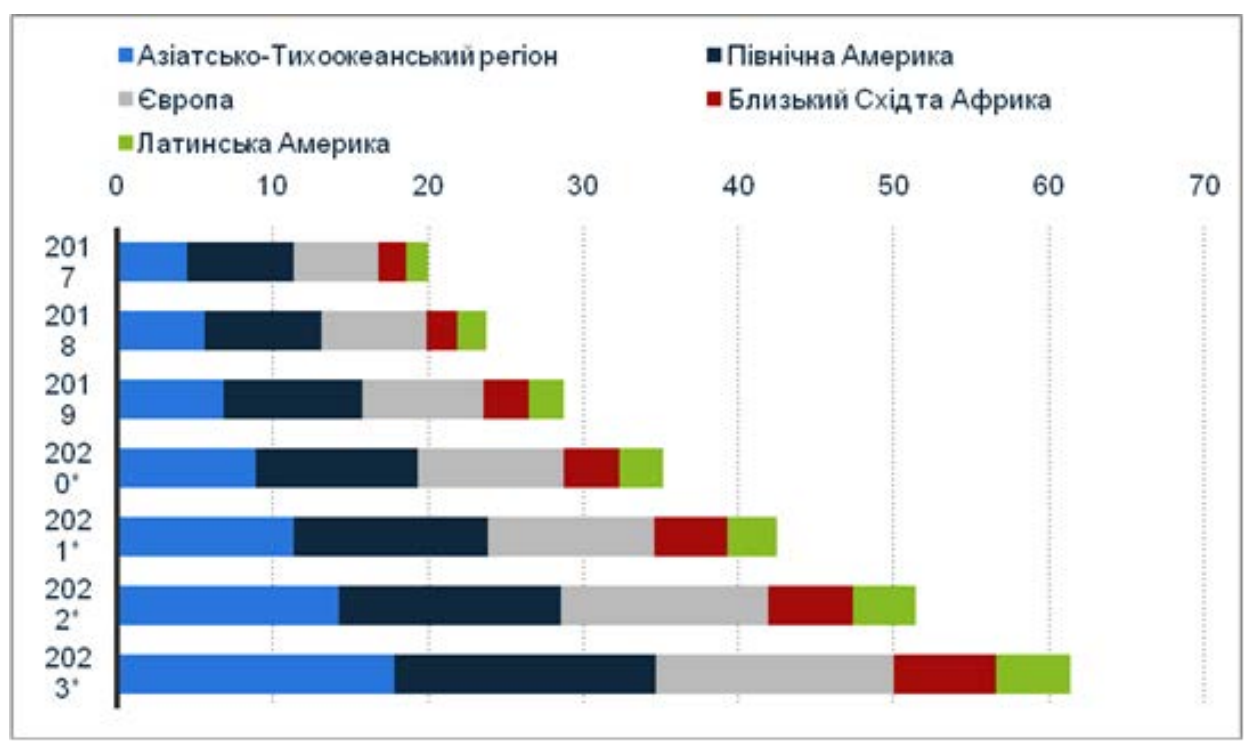

Рис. 1. Ринкова оцінка вартості сегмента розумних мереж у розрізі регіонів, млрд дол [8]

енергоресурсах, попит на які зростатиме щорічно на 1,7\% і досягне у 2030 р. рівня 15,3 млрд т нафтового еквівалента (т н. е.). Попит на нафту зросте з 9,7 млн т/день у 2000 р. до 16,3 млн т/день у 2030 р., водночас основним споживачем виступатиме транспортна галузь. Обсяги споживання природного газу подвояться, а частка ринку зросте із 24,5 до 28\% [10].

Нині Свропейський Союз значною мірою покладається на імпорт енергоресурсів, надалі дана тенденція буде зберігатися. У 2020 р. ступінь залежності Європейського Союзу від імпорту енергоносіїв у середньому становитиме 70\% (Таблиця 2).

Реформування енергетичного ринку Євросоюзу відбувається так. Для подолання проблеми імпортозалежності в Європейському Союзі було розроблено документ «Енергетика 2020. Стратегія конкурентної, сталої та безпечної енергії». Цим документом передбачено скорочення викидів парникових газів в атмос- ферне повітря на 20\%, збільшення частки відновлювальних джерел у балансі енергоносіїв до 20\% і підвищення рівня енергоефективності на 20\%.

Таблиця 2. Частка імпорту в енергетичному балансі EC [10]

\begin{tabular}{|c|c|c|c|}
\hline \multirow{2}{*}{ Рік } & \multicolumn{3}{|c|}{ Залежність від імпорту, \% } \\
\cline { 2 - 4 } & Тверде паливо & Нафта & Природний газ \\
\hline 1990 & 19,9 & 80,0 & 45,5 \\
\hline 2000 & 30,6 & 75,7 & 48,8 \\
\hline 2010 & 39,5 & 84,5 & 62,2 \\
\hline 2012 & 42,2 & 86,5 & 65,8 \\
\hline 2013 & 44,1 & 87,4 & 65,2 \\
\hline 2014 & 45,6 & 87,4 & 67,2 \\
\hline 2015 & 42,0 & 88,6 & 66,0 \\
\hline 2020 & 50,0 & 86,0 & 75,0 \\
\hline 2030 & 66,0 & 88,0 & 81,0 \\
\hline
\end{tabular}

Таблиця 3. Індикативні цілі з енергоощадності у країнах ЄC [11, с. 50-51]

\begin{tabular}{|c|c|c|c|c|c|}
\hline \multirow{2}{*}{ Країни } & \multicolumn{2}{|c|}{ Кінцеве споживання енергії, млн т н.е. } & \multirow{2}{*}{ Країни } & \multicolumn{2}{|c|}{ Кінцеве споживання енергї, млн т н.е. } \\
\cline { 2 - 3 } \cline { 5 - 5 } & $\mathbf{2 0 1 2} \mathbf{~ p . ~}$ & $\mathbf{2 0 2 0} \mathbf{~ p . ~}$ & & $\mathbf{2 0 1 2} \mathbf{~ p . ~}$ & $\mathbf{2 0 2 0}$ p. \\
\hline Австрія & 27,3 & 26,3 & Люксембург & 4,2 & 4,2 \\
\hline Бельгія & 36,6 & 32,5 & Мальта & 0,4 & 0,5 \\
\hline Болгарія & 9,2 & 9,2 & Нідерланди & 51,1 & 52,2 \\
\hline Великобританія & 133,8 & 157,8 & Польща & 63,6 & 70,4 \\
\hline Угорщина & 14,7 & 18,2 & Португалія & 16,2 & 17,4 \\
\hline Німеччина & 213,1 & 194,3 & Румунія & 22,7 & 30,3 \\
\hline Греція & 16,3 & 20,5 & Словаччина & 10,3 & 10,4 \\
\hline Данія & 14,1 & 14,8 & Словенія & 4,9 & 5,1 \\
\hline Ірландія & 10,7 & 11,7 & Фінляндія & 25,3 & 26,7 \\
\hline Іспанія & 83,2 & 82,9 & Франція & 150,8 & 131,4 \\
\hline Італія & 119,0 & 126,0 & Хорватія & 5,9 & 9,2 \\
\hline Кіпр & 1,8 & 2,2 & Чехія & 24,1 & 25,3 \\
\hline Латвія & 4,0 & 4,5 & Швеція & 32,4 & 2,4 \\
\hline Литва & 4,8 & 4,3 & Естонія & 2,9 & 2,8 \\
\hline
\end{tabular}


Директивою Європейського Союзу з енергетичної ефективності 2012/27/СC (Energy Efficiency Directive, EED) встановлено такі індикативні цілі з енергоощадності, яких повинна досягти країна, виходячи з рівня національного економічного розвитку (Таблиця 3).

Результативність реформ в енергетичному секторі Свропейського Союзу передусім зумовлена запро- вадженням положень Третього енергетичного пакету. Цим документом передбачено впровадження нових ощадливих технологій у сфері енергетики. Зокрема було доведено, що витрати споживачів на електроенергію можуть бути знижені на $13 \%$ у результаті запровадження розумних приладів обліку та сучасних систем управління енергоспоживанням [10, с. 28]. Доцільність

Таблиця 4. Європейські проєкти з інтелектуального обліку енергоспоживання [7, с. 33-36]

\begin{tabular}{|c|c|}
\hline Країна & Зміст проєкту \\
\hline Італія & $\begin{array}{l}\text { Енергоконцерном Enel за підтримки держави реалізовано найбільш ефективний і повномасштабний } \\
\text { проект Telegestore з упровадження системи Smart Metering, у рамках якого у фізичних осіб уже } \\
\text { встановлено приблизно } 33 \text { млн розумних лічильників. Нині інтелектуальна система обліку компанії } \\
\text { “Еnel” дозволяє економити у країні щорічно приблизно } 500 \text { млн євро, а період окупності витрат } \\
\text { становить 4-5 років. }\end{array}$ \\
\hline Іспанія & $\begin{array}{l}\text { Компанією “Еndesa”, яка є дочірнім підприємством “Enel Group”, передбачено замінити 100\% } \\
\text { традиційних приладів обліку на розумні лічильники по всій країні. У регіонах країни, які компанія } \\
\text { “Еndesa” обслуговує як дистриб’ютор електроенергії, установлено } 3,5 \text { млн приладів обліку, } \\
\text { включаючи Каталонію, Арагон, Канарські та Балеарські острови, Андалусію, Естремадуру. Заміна } \\
\text { лічильників для клієнтів відбувається абсолютно безкоштовно. Споживачі лише оплачують оренду } \\
\text { лічильника згідно з установленими тарифами. }\end{array}$ \\
\hline Португалія & $\begin{array}{l}\text { У Португалії метою проєкту Invo Grid є досягнення 20\%-го скорочення споживання електроенергії } \\
\text { завдяки впровадженню домашніх енергетичних установок, які забезпечують ефективне керування } \\
\text { електроспоживанням і мікрогенерацією. }\end{array}$ \\
\hline Швеція & $\begin{array}{l}\text { Ефективною є система дистанційного обліку електроенергії, упроваджена в місті Гетеборзі } \\
3 \text { населенням приблизно півмільйона людей. Компанія “Göteborg Energi” об’єднала } 265 \text { тис. приладів } \\
\text { обліку в мережу Zig Вее за допомогою } 8 \text { тис. концентраторів. Мережа Zig Beе є самопоновлюваною } \\
\text { i самоналаштовуваною. Якщо сигнал не може віднайти свій звичайний маршрут, то він надійде } \\
\text { на інші модулі Zig Bее з подальшим виходом у систему. }\end{array}$ \\
\hline
\end{tabular}

Таблиця 5. Еколого-економічний ефект від імплементації розумних технологій у житловий комплекс [7, с. 28]

\begin{tabular}{|c|c|c|c|}
\hline \multirow{2}{*}{ Група устаткування } & \multicolumn{2}{|c|}{ Економія енергії } & Зниження викидів СО, \\
\cline { 2 - 4 } & млрд євро на рік & млн т н.е. на рік & млн т на рік \\
\hline Побутова електротехніка & 4 & 2,6 & 13 \\
\hline Побутові водонагрівачі & 15 & 28 & 120 \\
\hline Котли & 30 & 47 & 39 \\
\hline Освітлення & 14 & & 50 \\
\hline Інше & 17 & 10 & 282 \\
\hline Усього & 80 & 87,6 & \\
\hline
\end{tabular}

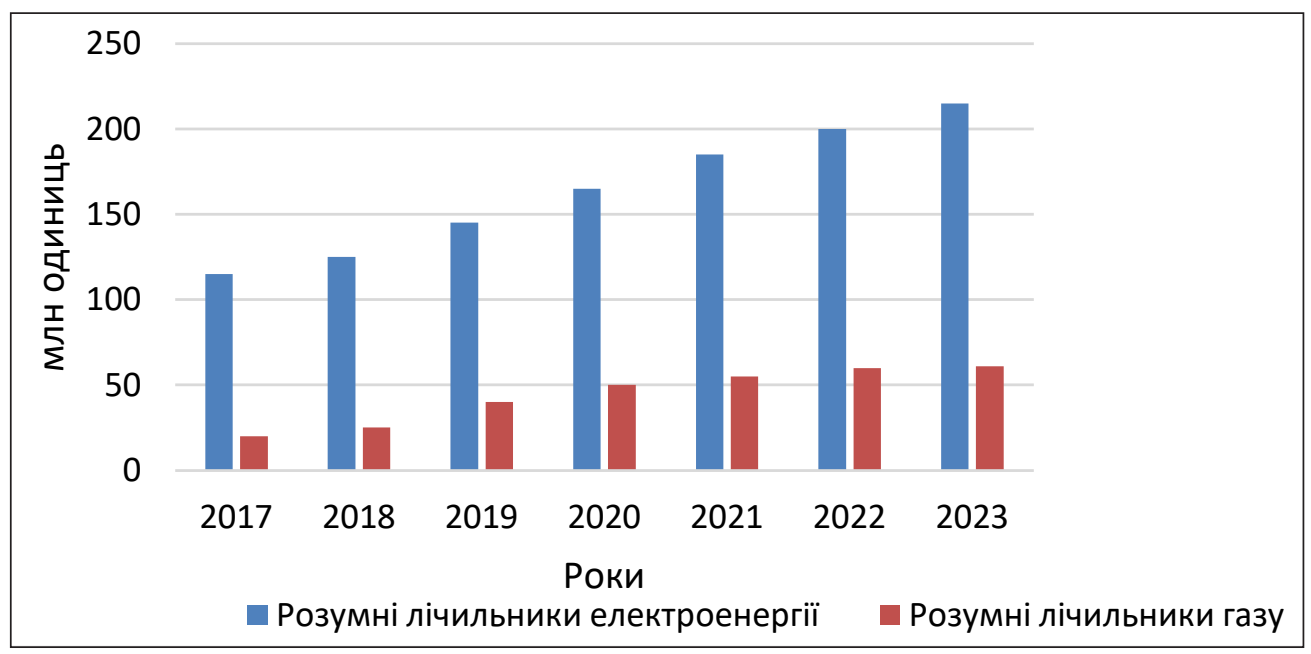

Рис. 2. Кількість встановлених розумних лічильників електроенергії та газу у країнах Європейського Союзу [12] 


\section{ЕКОНОМІКА ТА МЕНЕДЖМЕНТ № 4 2019}

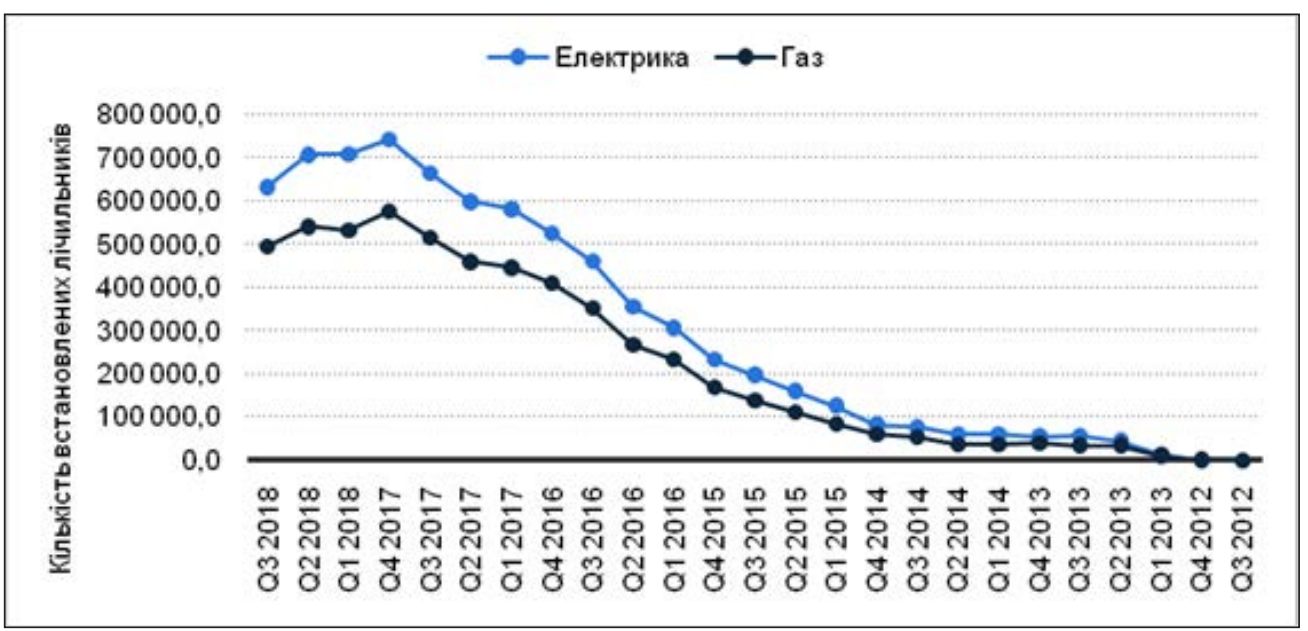

Рис. 3. Поквартальна динаміка побутового використання розумних лічильників у Великобританії [8]

створення сприятливих умов для участі споживачів у системі розподіленої генерації з імплементацією розумних мереж і розумних побутових електроприладів актуалізовано в «Пакеті Енергетичного союзу» у рамках Стратегії Енергетичного союзу ЄС до 2030 р.

Імплементація розумних мереж у країнах Свропейського Союзу відбувається на основі проєктного підходу. Упродовж останніх п'ятнадцяти років більше 5 млрд євро було інвестовано в понад 300 проєктів із розвитку розумних мереж електропостачання у країнах Свропейського Союзу, з яких приблизно 4 млрд інвестовано в розроблення розумних лічильників як одного з магістральних напрямів підвищення енергоефективності [7,c. 33]. Кращий європейський досвід інтелектуалізації системи електропостачання резюмуємо в Таблиці 4.

Упровадження розумних вимірювальних систем і приладів обліку електроенергії (Smart Metering) - основний шлях зниження в мережі нетехнологічних втрат. Пристрої систем обліку Smart Metering містять низку різних технологій, як-от зчитування, нагромадження і запам'ятовування інформації в режимі реального часу й оповіщення про втрати енергії, а також моніторинг якості надання комунальних послуг. Відмінною рисою інтелектуальності є наявність мікроконтролерів із незалежним живленням протягом 5-10 років, радіоканалів і комунікацій для передачі та прийняття інформації [7, с. 11]. Інакше кажучи розумні лічильники - це прилади, завдяки яким споживач здатний проактивно керувати процесом енергоспоживання в режимі онлайн. Дослідження Network Research доводить, що 90\% споживачів енергії, які мають можливість відстежувати на моніторі поточні витрати електроенергії в будинку, починають знижувати споживання енергії завдяки простому вимиканню невикористовуваних приладів $[7$, c. 33].
Завдяки ініціативі оснащення житлових будинків розумними технологіями у 2020 р. передбачається досягнення країнами Свропейського Союзу значного еколого-економічного ефекту (Таблиця 5).

Світовий попит на встановлення розумних лічильників у 2020 р. становитиме $60 \%$ від загального попиту на прилади обліку. За оцінками Міжнародного енергетичного агентства, світовий обсяг інвестицій у розвиток енергетики до 2030 р. становитиме приблизно 16 трлн дол. США, зокрема понад 2 трлн дол. у розвиток інтелектуальних мереж [7, с. 11-12].

Обсяг європейського ринку розумних лічильників iз передбаченням на 2023 р. має таку динаміку, представлену на рис. 2.

Як очікується, у 2020 р. 72\% європейських користувачів установлять розумні лічильники електроенергії та 40\% споживачів матимуть розумні лічильники газу. Динаміка встановлення розумних вимірювальних систем електроенергії та газу в житловому секторі Великобританії наведена на рис. 3. Наприкінці третього кварталу 2018 р. у Великобританії налічувалося 1128013 розумних приладів обліку побутового призначення.

Тенденцією останнього десятиліття $є$ розбудова розумних міст (Smart Cities), особливо у країнах Західної Свропи. Наведемо перелік європейських міст, які є лідерами в цьому, спираючись на індекс CIMI2019 (Cities in Motion Index) [13]: Лондон, Париж, Рейк'явік, Амстердам, Берлін, Копенгаген, Стокгольм, Відень, Хельсінкі, Осло.

У 2018 р. м. Мілан було визнано провідним розумним містом в Італії. Італійські проєкти з розбудови розумних міст репрезентовано на рис. 4 .

Інтенсивний розвиток і популярність розумних мереж у країнах Європейського Союзу потребують розбудови нової парадигми енергетичного сектора. Ідеться про формування інтелектоцентричної моделі енергетичного ринку. На нашу думку, обов'язковими елементами нової 


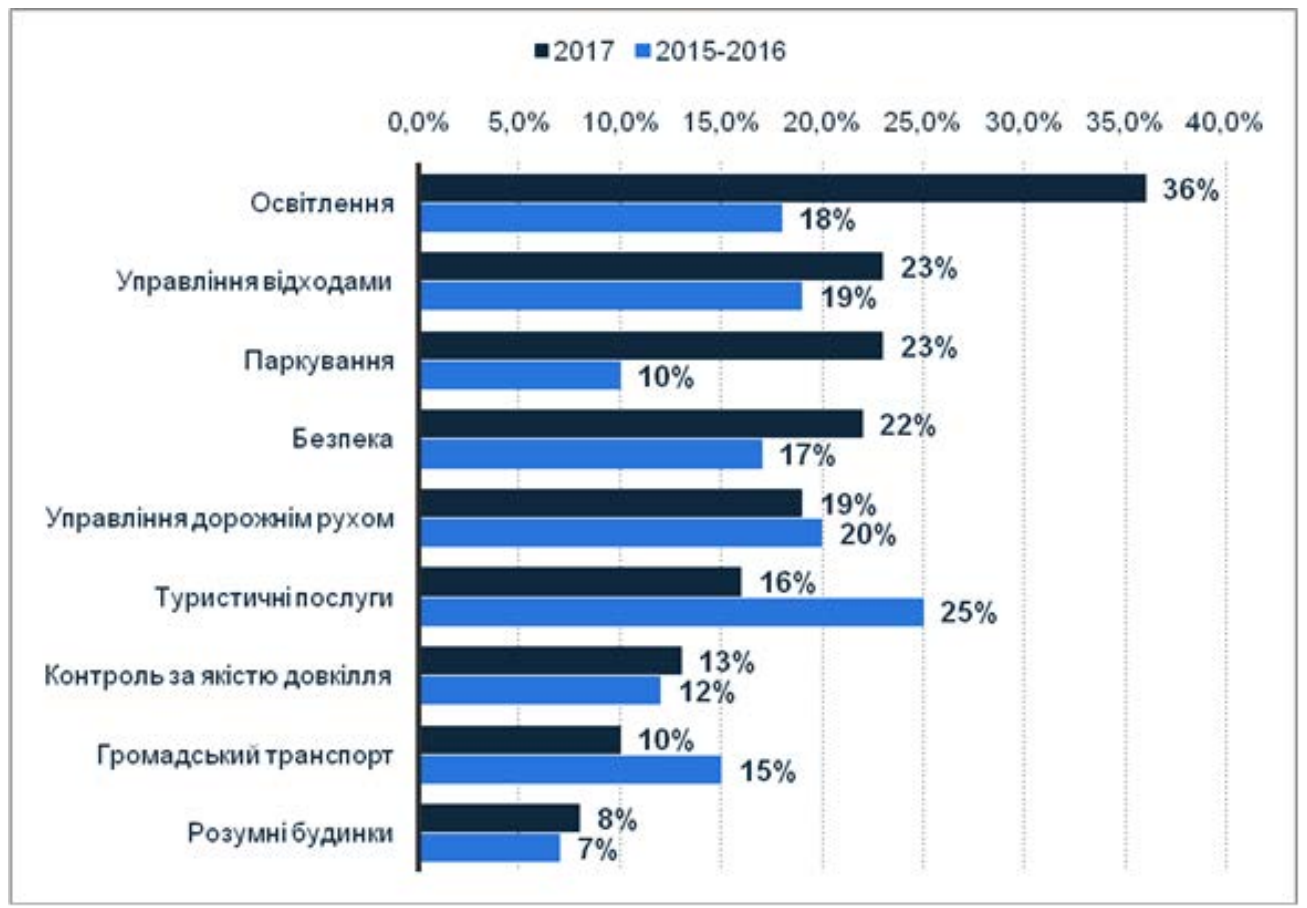

Рис. 4. Проєкти розбудови розумних міст в Італії [8]

моделі функціонування енергетичного комплексу повинні стати «розумні» ринки та «розумні» споживачі. Завдяки інтелектуально орієнтованому розвитку енергетичного комплексу Свропейський Союз може стати одним із регіонів із найбільш енергоефективною економікою у світі $[11$, c. 43$]$. Завдяки реформуванню енергетичного комплексу Європейському Союзу вдалося за останні 20 років знизити енергоємність валового внутрішнього продукту на $25 \%$ [11, с. 90$]$.

\section{ОБГОВОРЕННЯ ОТРИМАНИХ РЕЗУЛЬТАТІВ}

Розумні технології приносять відчутні економічні, екологічні та геостратегічні результати для країн Європейського Союзу. Так, вони сприяють:

- розбудові енергоефективної Свропи;

- формуванню спільного, інтегрованого енергетичного ринку;

- розширенню прав споживачів щодо вибору постачальника енергії;
- досягненню найвищого рівня енергетичної безпеки;

- посиленню лідерських позицій Європи в енергетичних технологіях;

- нарощуванню зовнішнього впливу енергетичного ринку СС.

\section{ВИСНОВКИ}

Особливістю енергетичного ринку Свропейського Союзу є обмеженість запасів первинних джерел енергії та їх нерівномірний територіальний розподіл. Таке становище енергетичного сектора потребує успішних реформ. Реформування енергоринків має насамперед зосередитися на розробленні та реалізації програм із підвищення енергетичної безпеки, енергоефективності й енергоощадності, що досягається завдяки впровадженню розумних технологій. Очікується, що в майбутньому обсяги електропостачання через розумні мережі зможуть перевищити 20\%.

\section{REFERENCES}

[1] Iskakov,A.Kobusko, I.(2016).Enerhoefektyvnistnatsionalnoiekonomikyvkontekstiiiekoloho-ekonomichnoibezpeky[Energy efficiency of a national economy in the context of its ecological and economic security]. Mekhanism rehuliuvannia ekonomiky, no. 3, pp. 88-96.

[2] Kytskai, L. (2013). Enerhoefektyvnist v Ukraini: analiz, problemy ta shliakhy pidvyshchennia [Energy efficiency in Ukraine: analysis, problems and ways of enhancing]. Innovatsiina ekonomika, no. 3, pp. 32-37.

[3] Suhodolia, O. (2005). Factory vplyvu na enerhoefektyvnist natsionalnoi ekonomiky [Factors of influence on energy efficiency of national economy]. Visnyk Natsionalnoi akademii derzhavnoho upravlinnia pry Prezudentovi Ukrainy, no. 1, pp. $236-247$.

[4] Barhatov, O. Kovalchuk, I. (2014). Problemy enerhozberezhennia v Ukraini [Problems of energy saving in Ukraine]. Enerhetyka ta kompiuterno-intehrovani tekhnolohii v APK, no. 1, pp. 56-57.

[5] Matvieieva, Yu. Kolosok, S. Vakulenko, I. (2019). Analizzarubizhnogodosvidushchodozabezpechenniaenerhetychnoie fektyvnostinaosnovimodeliSMARTGRID [The analysis of foreign experience to implementation energy efficiency on 
the basis of SMART GRID model]. Efektyvna ekonomika. Retrieved from: http://www.economy.nayka.com.ua/index. php?op=1\&z=6987.

[6] Matiushok, V. Bruno, S. Balashova, S. Gomonov, K. (2017). Vliianie SMART GRID i vozobnovliaemykh istochnikov energii na energoeffectivnost: zarubezhnyi opyt [The impact of SMART GRID and renewables on energy efficiency: foreign experience]. Vestnik RUDN. Seriia: Ekonomika, no. 4, pp. 583-598.[in Russian]

[7] SE "NEK Ukrenergo", (2015). Zarubizhnyi dosvid pidvyshchennia efektyvnosti peredavannia ta rozpodilu electroenerhii, optymizatsii vtrat electroenerhii $\mathrm{v}$ electromerezhakh vsikh rivniv napruhy [Foreign experience of improving the efficiency of transmission and distribution of electricity, optimization of electricity losses in power grids of all voltage levels]. Report, $85 \mathrm{p}$.

[8] STATISTA, (2019). Official web-site. Retrieved from: https://www.statista.com/ [in English]

[9] Renewable energy country attractiveness index, (2019). Retrieved from:https://www.ey.com/Publication/vwLUAssets/eyRECAI-Index-53-scores-ladder/\$FILE/ey-RECAI-Index-53-scores-ladder.pdf. [in English]

[10] SE "NEK Ukrenergo", (2017). Osnovni polozhennia enerhetychnykh stratehii ta prohram Evropeiskoho Soiuzu shchodo rozvytku enerhetychnoi sfery v umovakh formuvannia zahalnoievropeiskoho rynku electroenerhii [The main provisions of the European Union's energy strategies and programs for the development of the energy sector in the context of the formation of a pan-European electricity market]. Report, $93 \mathrm{p}$.

[11] SE "NEK Ukrenergo", (2017). Dosvid krain Yevrosoiuzu z pidvyshchennia enerhoevektyvnosti, enerhoaudytu ta enerhomenedzhmentu $\mathrm{z}$ enerhooshchadnosti $\mathrm{v}$ ekonomitsi krain [EU countries' experience in improving energy efficiency, energy audit and energy management in the economy of countries]. Report, $114 \mathrm{p}$.

[12] Smart Meteringin Europe, 2019. Retrieved from: http://www.berginsight.com/ReportPDF/ProductSheet/bi-sm14-ps.pdf. [in English]

[13] Top 10 smartcitiesin Europe, 2019. Retrieved from: https://europe.businesschief.com/top10/2606/Top-10-smart-cities-in-Europe.

\section{СПИСОК ВИКОРИСТАНОЇ ЛІТЕРАТУРИ}

[1] Іскаков А., Кобушко I. Енергоефективність національної економіки в контексті її еколого-економічної безпеки. Механізм регулювання економіки. 2016. № 3. С. 88-96.

[2] Кицкай Л. Енергоефективність в Україні: аналіз, проблеми та шляхи підвищення. Інноваційна економіка. 2013 . № 3. С. 32-37.

[3] Суходоля О. Фактори впливу на енергоефективність національної економіки. Вісник Національної академії державного управління при Президентові України. 2005. № 1. С. 236-247.

[4] Бархатов О., Ковальчук I. Проблеми енергозбереження в Україні. Енергетика та комп'ютерно-інтегровані технології в АПК. 2014. № 1. С. 56-57.

[5] Матвєєва Ю., Колосок С., Вакуленко І. Аналіз зарубіжного досвіду щодо забезпечення енергетичної ефективності на основі моделі SMARTGRID. Ефективна економіка. 2019. URL: http://www.economy.nayka.com.ua/index. php?op=1\&z=6987.

[6] Влияние SMARTGRID и возобновляемых источников энергии на энергоэффективность: зарубежный опыт / В. Матюшок и др. Вестник Российского университета дружбы народов. Серия «Экономика». 2017. № 4. С. 583-598.

[7] ДП «НЕК Укренерго». Зарубіжний досвід підвищення ефективності передавання та розподілу електроенергії, оптимізації втрат електроенергії в електромережах всіх рівнів напруги. Київ, 2015. 85 с.

[8] Official website of STATISTA. 2019. URL: https://www.statista.com/.

[9] Renewable energy country attractiveness index. 2019. URL: https://www.ey.com/Publication/vwLUAssets/ey-RECAIIndex-53-scores-ladder/\$FILE/ey-RECAI-Index-53-scores-ladder.pdf.

[10] ДП «НЕК Укренерго». Основні положення енергетичних стратегій та програм Свропейського Союзу щодо розвитку енергетичної сфери в умовах формування загальноєвропейського ринку електроенергії. Київ, 2017. 93 с.

[11] ДП «НЕК Укренерго». Досвід країн Свросоюзу з підвищення енергоефективності, енергоаудиту та енергоменеджменту з енергоощадності в економіці країн. Київ, 2017. 114 с.

[12] Smart Meteringin Europe. 2019. URL: http://www.berginsight.com/ReportPDF/ProductSheet/bi-sm14-ps.pdf.

[13] Top 10 smart cities in Europe. 2019. URL: https://europe.businesschief.com/top10/2606/Top-10-smart-cities-in-Europe. 